\title{
The hydrology and methylmercury dynamics of a Precambrian Shield headwater peatland
}

\author{
Brian A. Branfireun, ${ }^{1}$ Andrew Heyes, and Nigel T. Roulet ${ }^{1}$ \\ Department of Geography and Centre for Climate and Global Change Research \\ McGill University, Montreal, Quebec, Canada.
}

\begin{abstract}
A hydrobiogeochemical investigation of a small headwater peatland located in the Experimental Lakes Area, northwestern Ontario, Canada, examined the surface and subsurface hydrologic pathways and their relation to the movement and spatial variability of methylmercury $\left(\mathrm{CH}_{3} \mathrm{Hg}^{+}\right)$. The hydrology of the peatland controls the mass flux of $\mathrm{CH}_{3} \mathrm{Hg}^{+}$to a downstream pond from the terrestrial ecosystems, and influences the production and/or accumulation of $\mathrm{CH}_{3} \mathrm{Hg}^{+}$in the peatland. Distinct zones of groundwater recharge and discharge were observed within the peatland, and these corresponded, to low and high $\mathrm{CH}_{3} \mathrm{Hg}^{+}$concentrations, respectively, in pore water. The magnitude and flux of $\mathrm{CH}_{3} \mathrm{Hg}^{+}$from the peatland was governed by the area of the peatland and surrounding uplands contributing runoff. There was a threefold increase in $\mathrm{CH}_{3} \mathrm{Hg}^{+}$concentration as stream base flow passed from the origin of the stream at the hillslope-peatland margin to the stream outlet at the peatland-lake interface. This relative increase in concentration was maintained during storm flow conditions even though the discharge was up to 10 times greater, indicating that the peatland is a large source of $\mathrm{CH}_{3} \mathrm{Hg}^{+}$. Methylmercury-laden peat pore water found near the surface of the peatland in areas of groundwater discharge moves to the stream as the water table rises to the peat surface. Of a total of $12.6 \mathrm{mg} \mathrm{CH} \mathrm{CHg}^{+}$leaving the peatland during the 112-day study period, less than $1 \%$ was transported directly by groundwater, $41 \%$ was transported in stream base flow, and the remaining $58 \%$ was transported by storm flow. However, storm flow conditions occurred only $16 \%$ of the time, indicating the significance of episodic $\mathrm{CH}_{3} \mathrm{Hg}^{+}$flux from headwater catchments on the Precambrian Shield.
\end{abstract}

\section{Introduction}

The hydrology of peatlands has received attention because of its importance in the initiation and maintenance of peatland ecosystems [e.g., Siegel and Glaser, 1987] and its role in the mass flux of water and chemicals within peatlands [e.g., $\mathrm{He}$ mond, 1980; Verry and Timmons, 1982]. However, few studies have attempted to examine how surface and subsurface flow pathways connect within a peatland or to integrate the peatland into the catchment hydrologic system. This knowledge is essential for an understanding of the transport and transformation of biogeochemically important elements within peatlands. In this paper we describe a study of the transport of methylmercury $\left(\mathrm{CH}_{3} \mathrm{Hg}^{+}\right)$in a northern peatland catchment and demonstrate the primary role hydrologic flowpaths play in determining the flux of $\mathrm{CH}_{3} \mathrm{Hg}^{+}$.

Observations of elevated mercury concentrations in fish from Canada, the United States, and Sweden indicate a need for research on mercury cycling in aquatic environments. Recent work suggests that $\mathrm{CH}_{3} \mathrm{Hg}^{+}$accounts for $95 \%$ of the mercury found in fish [Bloom, 1992], even though it accounts for no more than $10 \%$ of the total mercury in most environments [Kelly et al., 1995]. Little is known about the production

\footnotetext{
${ }^{1}$ Formerly at Department of Geography, York University, North York, Ontario, Canada.

Copyright 1996 by the American Geophysical Union.

Paper number 96WR00790.

0043-1397/96/96WR-00790\$09.00
}

or the pathways of biological uptake of $\mathrm{CH}_{3} \mathrm{Hg}^{+}$in the natural environment.

Long-range transport and subsequent direct deposition, and surface runoff have been identified as the two principal vectors of mercury input to aquatic systems [Iverfeldt and Johansson, 1988; Fitzgerald and Watras, 1989; Sorenson et al., 1990; Iverfeldt, 1991; Lindqvist et al., 1991; Meili, 1991]. Research on the exchange of mercury between uplands and lakes has concentrated on mineral hillslopes. Meili [1991] suggested that shallow soils overlying igneous bedrock favor the transport of mercury-laden organic matter to surface waters and that the short residence time of water in the shallow soils leads to the rapid transport of mercury to lakes. Aastrup et al. [1991] modeled mercury transport from a forested upland catchment that contained a treeless bog and estimated that of a total flux of $3.4 \mathrm{~g}$ $\mathrm{km}^{-1} \mathrm{y}^{-1}, 75 \%$ of mercury transport occurred in the top $20 \mathrm{~cm}$ of the soil. No work of this type has yet been undertaken for methylmercury.

Recent work [Driscoll et al., 1994; St. Louis et al., 1994; Rudd, 1995; Bishop et al., 1995a,b; Krabbenhoft et al., 1995] demonstrated that peatlands are important sources of $\mathrm{CH}_{3} \mathrm{Hg}^{+}$and may also contain sites of methylation. In the boreal forest region of the Precambrian Shield, peatlands are very common and are usually located between hillslopes and lakes. St. Louis et al. [1994] found a fourfold to fifteenfold greater yield of $\mathrm{CH}_{3} \mathrm{Hg}^{+}$from catchments containing peatlands than purely upland catchments. They suggest that the contribution of $\mathrm{CH}_{3} \mathrm{Hg}^{+}$per unit area of wetland is $26-79$ times greater than that from upland terrain.

While the presence of peatlands results in increased export 


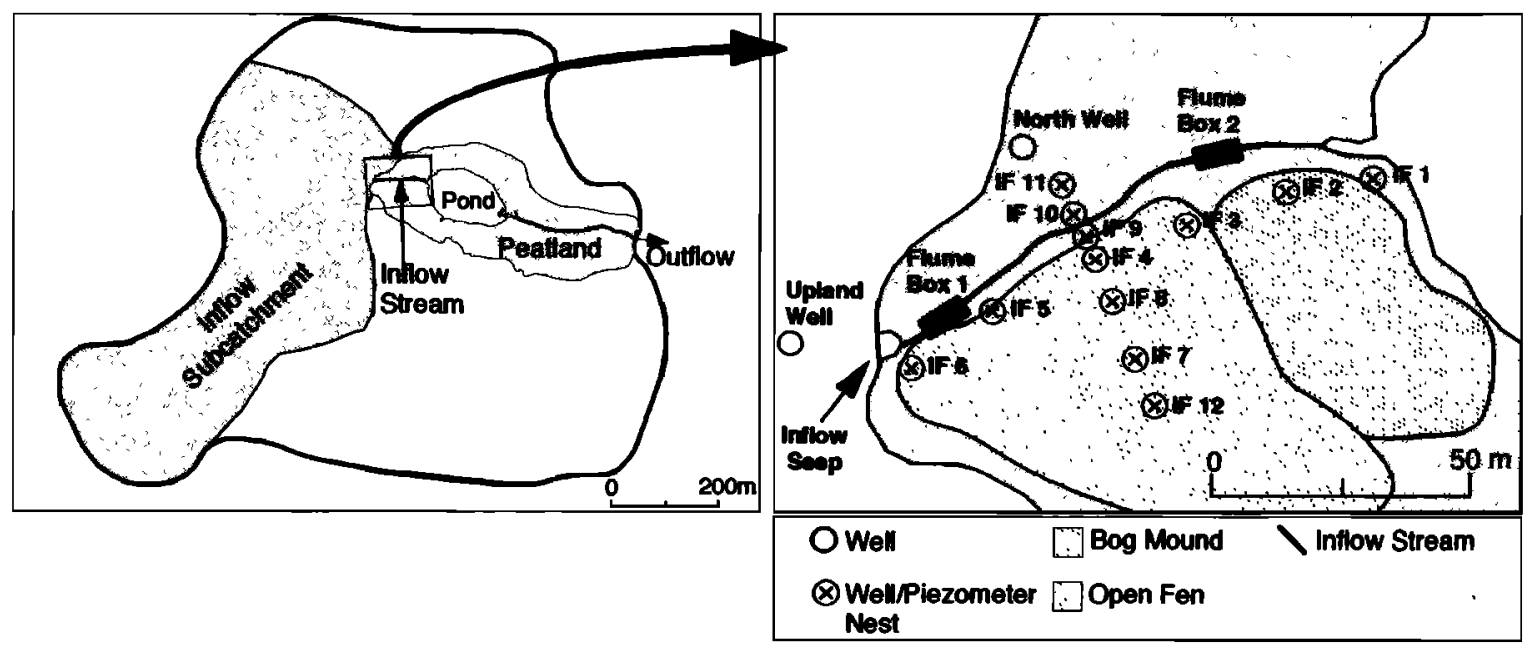

Figure 1. (left) Map of the 632 catchment and (right) detailed view of the instrument sites and significant landforms.

of $\mathrm{CH}_{3} \mathrm{Hg}^{+}$, the pathways by which the $\mathrm{CH}_{3} \mathrm{Hg}^{+}$enters the downstream systems are not well known. Aside from biotic uptake and relocation, the transport of total $\mathrm{Hg}$ must be linked to surface water flow [e.g., Aastrup et al., 1991] and/or groundwater flow [e.g., Krabbenhoft and Babiarz, 1992]. St. Louis et al. [1994] found that a headwater peatland yielded $\mathrm{CH}_{3} \mathrm{Hg}^{+}$at about 3 times the rates of riparian wetlands annually and that this may be related to the residence time of water in headwater systems. We hypothesize that not only is the residence time significant, but also the pathways by which water moves through the catchment to the downstream system are important.

The objectives of this paper are (1) to determine the surface water and groundwater flow in a Precambrian Shield headwater peatland under base flow and storm flow conditions, (2) to relate the spatial variation in $\mathrm{CH}_{3} \mathrm{Hg}^{+}$concentrations in a peatland to the hydrologic pathways of the peatland, and (3) to estimate the fluxes of $\mathrm{CH}_{3} \mathrm{Hg}^{+}$via surface and subsurface flow paths during base flow and storm flow conditions.

\section{Site Description}

The study was conducted on a small Precambrian Shield headwater catchment (basin 632) located in the Experimental Lakes Area (ELA) $\left(49^{\circ} 40^{\prime} \mathrm{N}, 93^{\circ} 43^{\prime} \mathrm{W}\right)$ near Kenora, Ontario, Canada, as part of the Experimental Lakes Area Reservoir Project (ELARP). The area consisted of the inflow subcatchment (632 inflow) of the headwater basin of lake 632. The climate of the study area is classified as boreal, cold temperate. Average monthly air temperatures based on data from 19691989 ranged from $-16.5^{\circ} \mathrm{C}$ for January to $20.1^{\circ} \mathrm{C}$ for July, and average total annual precipitation was $507.6 \mathrm{~mm}, 36 \%$ of which fell as snow [Beaty and Lyng, 1989].

The subcatchment contained a hillslope $\left(1.2 \times 10^{5} \mathrm{~m}^{2}\right)$ and the inflow portion of a pondside peatland containing both a mineral-poor fen and a raised peat mound $\left(6.0 \times 10^{3} \mathrm{~m}^{2}\right)$. A surface stream that traversed the peatland originated at a small seep at the hillslope-peatland interface (Figure 1). The bedrock geology is typical of Archean granitic-gneissic terrain and is largely unfractured. Soils in the upland portion of the catchment range from silty loams of glaciolacustrine origin to patches of coarse till. Stratigraphic information from peat cores indicates that the peatland lies in a shallow bedrock basin with a deep central depression beneath the pond (Figure 2). Bedrock was overlain by well-sorted sand and gravel greater than $1 \mathrm{~m}$ in depth in the inflow area, and by fine silts and clay in the deeper central depression. Above the inorganic sediments, cyperaceous and detrital peat was found toward the hillslope-peatland interface, and ericaceous peat was found closer to the pond. Limnic peat and gyttja were found in deep cores taken near the pond margin. A surficial accumulation of dead Sphagnum spp. overlain by living Sphagnum spp. was nearly ubiquitous across the terrestrial portion of the peatland. Maximum peat depth is approximately $7 \mathrm{~m}$, and average peat depth is approximately $2 \mathrm{~m}$.

Upland vegetation comprises an overstory of jackpine (Pinus banksiana) and black spruce (Picea mariana) with scattered paper birch (Betula papyrifera) (J. Bubier, personal communication, 1995). Bedrock outcrops are colonized by lichens (both foliose and fruticose forms), juniper (Juniperus virginiana), and mosses (Racomitrium sp.).

Peatland surface vegetation is dominated by Sphagnum spp. (S. angustifolium, S. fuscum, and S. magellanicum) with shrubs such as Labrador tea (Ledum groenlandicum) and leatherleaf (Chamedaphne calyculatta) in the more ombrotrophic area and sedges (Carex spp.) in the more mineral-poor fen zones around seeps and streams (J. Bubier, personal communication, 1995). The peatland overstory is open and consists almost entirely of black spruce.

\section{Methods}

Fluxes of water to, from, and within the peatland were examined from mid-May to mid-October 1993. The locations of the sample sites referred to in the following section are shown in Figure 1.

\section{Hydrologic Measurements}

Precipitation intensity was recorded using a tipping bucket rain gauge. Biweekly total rainfall was measured using a standard Atmospheric Environment Service (AES) rain gauge.

A total of 13 piezometer nests and 15 wells were installed in two perpendicular transects across the peatland so that hydraulic head and water table position could be measured (Figure 1). 


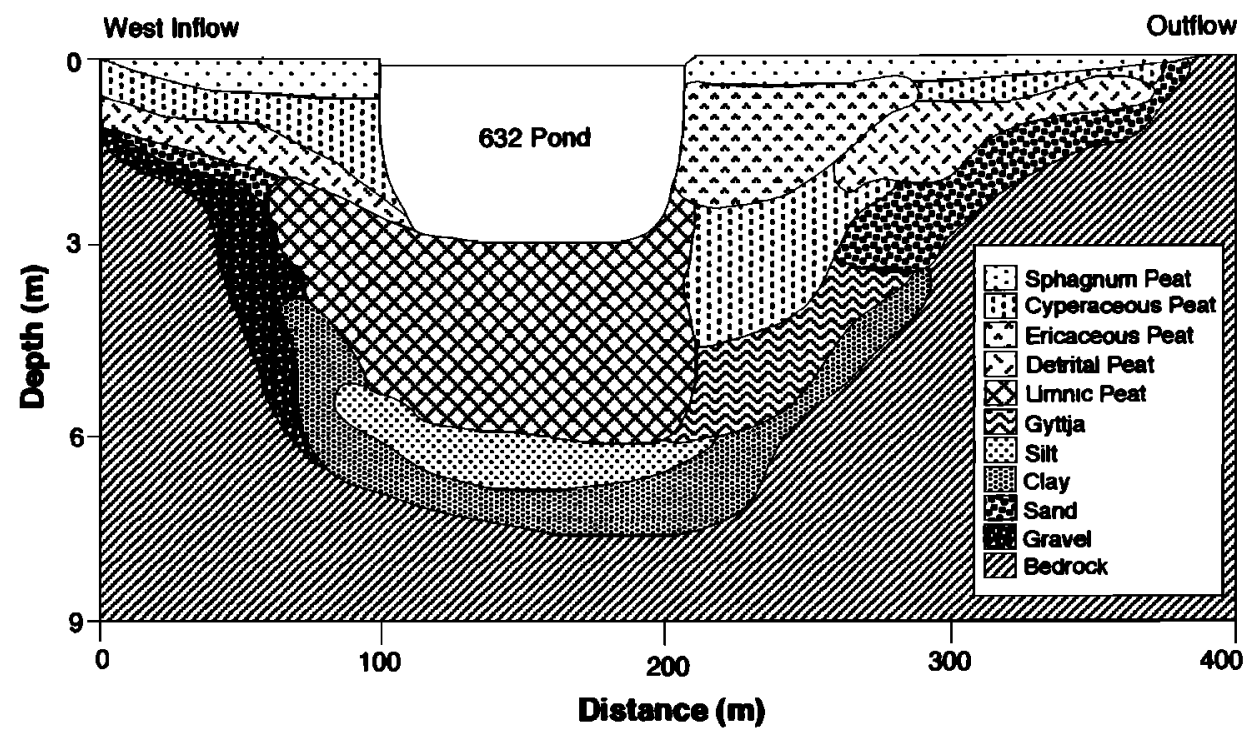

Figure 2. Stratigraphy of the 632 peatland. Transect is from west to east along the long axis of the peatland. Data courtesy of B. Warner, Department of Geography, University of Waterloo, Waterloo, Canada.

Piezometers ranging in length from $0.5 \mathrm{~m}$ to $3.0 \mathrm{~m}$ were constructed from polyvinyl chloride $(P V C)$ pipe $(I D \approx 1 \mathrm{~cm})$. Each piezometer had a $20-\mathrm{cm}$ slotted well point covered with a $40-\mu \mathrm{m}$ Nitex ${ }^{\circledR}$ mesh to prevent clogging. Hydraulic conductivity for selected piezometer nests was determined using Hvorslev's method [Freeze and Cherry, 1979].

Water table wells were constructed of PVC pipe perforated along their entire length. Water levels were measured manually periodically, but at some locations, water levels were recorded every $60 \mathrm{~s}$ (with potentiometric water level recorders), and 30-min averages were stored in a data logger.

Flume boxes were installed at two locations on the inflow stream to monitor channelized surface flow (Figure 1). The water level in each flume box was measured continuously in a stilling well located at the front of the box. A stage-discharge relationship was developed using the velocity-area method, and velocity was determined for different stages with a Pygmy current meter.

A small number of samples of surface water and groundwater were taken in August for analysis of $\delta^{18} \mathrm{O}$, and were sampled in $60-\mathrm{mL}$ Nalgene ${ }^{(}$bottles fitted with displacement caps. The $\delta^{18} \mathrm{O}$ of the samples was analyzed at the Environmental Isotope Laboratory, Department of Earth Sciences, University of Waterloo, Waterloo, Ontario, Canada.

\section{Methylmercury Sampling and Analysis}

$\mathrm{CH}_{3} \mathrm{Hg}^{+}$concentrations were determined for surface water and groundwater under base flow and storm flow conditions. A total of 45 water samples were collected for analysis. Samples were obtained in May, June, and August 1993 and in August and September 1994 under baseflow conditions, and on July 28-31, 1993, under stormflow conditions after a rainfall of 38 $\mathrm{mm}$. The locations of the peat pore water profile sample sites are shown in Figure 1. IF 2 was located in a raised peat mound characterized as ombrotrophic (water inputs by precipitation only). IF 6 and 7 were located in a mineral-poor fen sustained by groundwater discharge. IF 11 was in a transition bog zone with primarily recharge-lateral groundwater flow. Pore water samples were drawn using PVC piezometers ( $\geq 50 \mathrm{~cm}$ depth) and a portable peat "sipper" (<50 cm depth). The PVC piezometers were used for deep sampling after comparative analysis of mercury samples drawn from Teflon ${ }^{\circledR}$ piezometers at the same sites revealed concentration differences within acceptable limits of spatial variation and analytical error (i.e., analytical variation between replicate samples was $10 \%$; spatial variation in concentration from adjacent Teflon piezometers was approximately $22 \%$; and concentration differences between adjacent Teflon and PVC piezometers was $17 \%$ ). The portable peat sipper was a stainless steel tube fitted with a slotted $(2.5 \mathrm{~cm})$ Teflon intake at one end. The sipper is inserted into the peat to the desired depth, and the sample is drawn through the intake through a Teflon tube inside the sipper to a Teflon transfer container.

$\mathrm{CH}_{3} \mathrm{Hg}^{+}$samples for stream concentrations were taken at three locations: the seep at the base of the hillslope that sustains stream base flow, halfway between the hillslope and the pond, and in the stream just before it flows into the pond. Surface water samples were taken by placing the Teflon sample bottle directly into the stream or surface pool. Additional grab samples were taken from surface water on the peatland and overland flow in the upland portion of the subcatchment in order to determine $\mathrm{CH}_{3} \mathrm{Hg}^{+}$concentration of storm runoff.

Ultraclean sampling protocol was followed. Vinyl gloves were worn at all times, and the sample bottle was protected from contamination by double-bagging with two polyethylene bags and placing it in a clean transport container. One field worker handled potentially contaminated sampling articles while another handled the sample bottle only. All Teflon sampling gear (bottles, peat sippers, and piezometers) was precleaned with hot nitric acid and deionized water.

Peat pore water samples were passed immediately through a

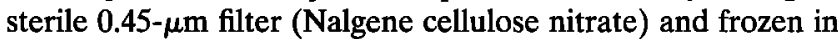
Teflon bottles. Stream and surface water samples were not filtered, but samples were rejected if visible particles were present. $\mathrm{CH}_{3} \mathrm{Hg}^{+}$analysis was performed at ELA in a mercury clean room using a technique modified from Bloom and Fitzgerald [1988] and Horvat et al., [1993]. Humics were removed from the samples using a subboiling distillation [Horvat 


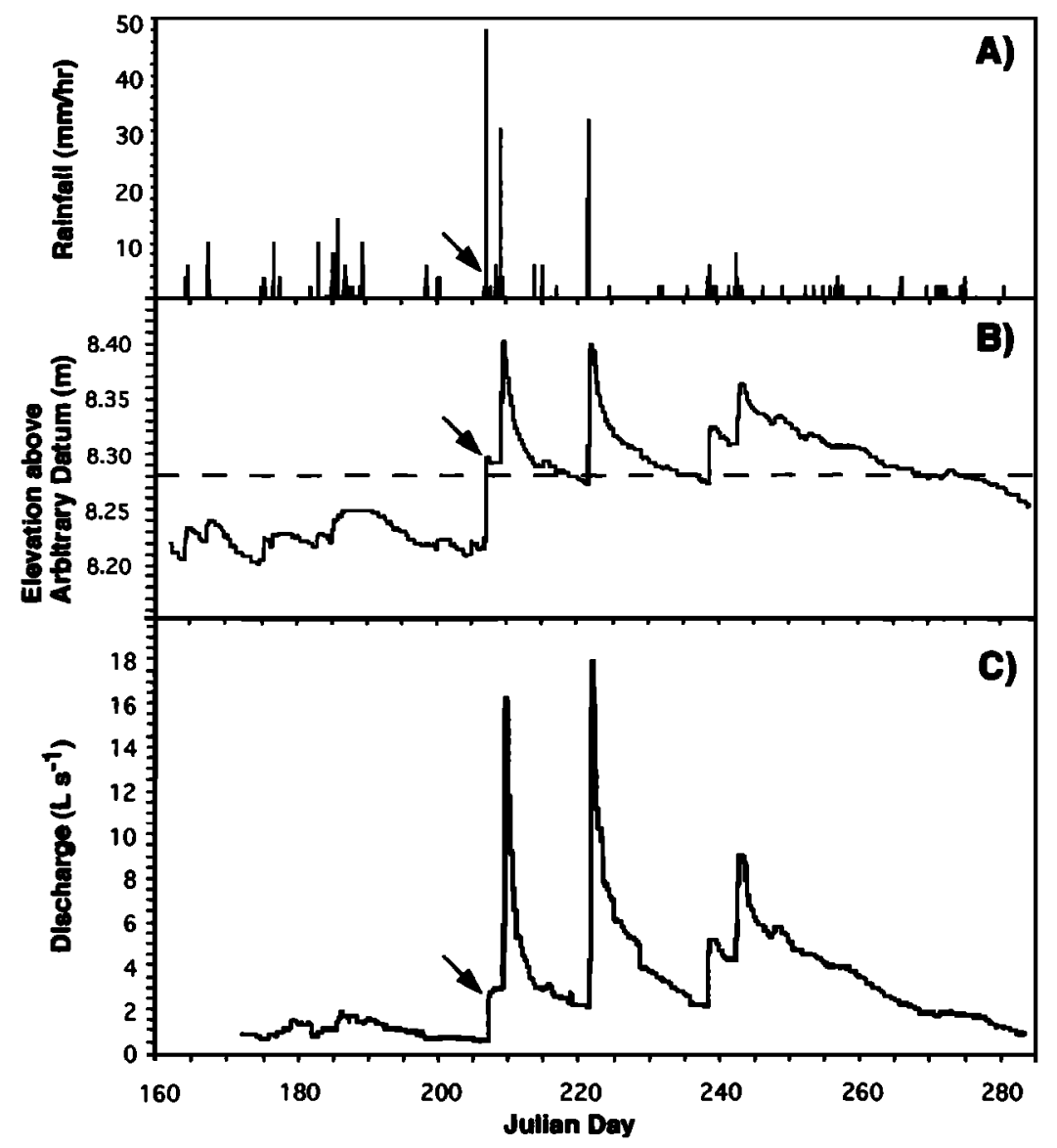

Figure 3. (a) Rainfall recorded, (b) changes in water table elevation in the peatland (dashed line indicates the peat surface elevation above arbitrary datum), and (c) inflow stream discharge measured at flume box 2 , for the study period. Arrows indicate the rainfall of July 25 and the resultant changes in water table and streamflow regimes.

et al., 1993]. The $\mathrm{Hg}$ in the distillate was then ethylated and purged with nitrogen onto Tenax ${ }^{\circledR}$. The Tenax was flash heated in a stream of helium, releasing the mercury, which was speciated chromatographically, combusted to $\mathrm{Hg}^{\mathbf{0}}$, and measured using atomic fluorescence [Bloom and Fitzgerald, 1988]. The detection limit was $0.01 \mathrm{ng} \mathrm{L}^{-1}$ as $\mathrm{Hg}$. All $\mathrm{CH}_{3} \mathrm{Hg}^{+}$concentrations are presented in nanograms per liter as $\mathrm{Hg}$.

\section{Results}

\section{Hydrology}

Precipitation. The record of continuous data began on June 11 and ended on October 10, 1993. During this period, $362 \mathrm{~mm}$ of rain was recorded, of which $37.6 \%$ occurred in three events in late July and early August: July 25 (day 206), 44 mm; July 26 (day 207), $38 \mathrm{~mm}$; and August 9 (day 221), 54 mm (see Figure 3a).

Continuous well records indicate two different water table regimes. Rainfall of July 25 (day 206) and July 27 (day 208) substantially elevated the water table in the entire peatland above the pre-July 25 "base flow" position. A plot of water table position from a peatland well (Figure $3 \mathrm{~b}$ ) illustrates the two water table regimes and typical water table behavior in response to rainfall. The frequency of occurrence of water table position at IF 7 and IF 11 is presented in Figure 4. These data may be used to differentiate between the sampling sites for the range and duration of water table fluctuations over the study period.

Surface flow. Base flow in the inflow stream that flows across the peat surface and into the pond comprises shallow groundwater flow emerging in a seep at the base of the hillslope at the western margin of the peatland (see Figure 1) and a small amount of seepage input from the peatland groundwater system (see below). Mean discharge of inflow stream was $3.0 \mathrm{~L} \mathrm{~s}^{-1}$, and the maximum and minimum instantaneous discharge was 18 and $0.6 \mathrm{~L} \mathrm{~s}^{-1}$ (Figure 3c). Prior to July 25 (day 206), when the water table was low, mean discharge was $1.0 \mathrm{~L}$ $\mathrm{s}^{-1}$, and the hydrographic response to rainfall was subdued. After July 25, when the water table in the catchment was elevated, a series of larger rainfalls increased the inflow stream mean discharge to $3.9 \mathrm{~L} \mathrm{~s}^{-1}$. Rainfall-induced peak discharge during this period was an order of magnitude higher than that prior to July 25 . Total discharge from the inflow stream over the period of measurement (June 20 to October 10) was $2.88 \times$ $10^{7} \mathrm{~L}(229 \mathrm{~mm})$, yielding a runoff ratio (runoff/precipitation) of 0.58 . Streamflow occurred for the entire study period, even under very dry conditions.

Groundwater flow. Calculated values of hydraulic conductivity $K$ are presented in Figure 5a. They range over 4 orders of magnitude $\left(1.1 \times 10^{-5}\right.$ to $\left.4.6 \times 10^{-9} \mathrm{~m} \mathrm{~s}^{-1}\right)$. The highest $K$ was found in the shallowest piezometers located in peat $(0.5 \mathrm{~m})$ and at depth in the sand underlying IF 4, IF 7 and IF 11 . The 


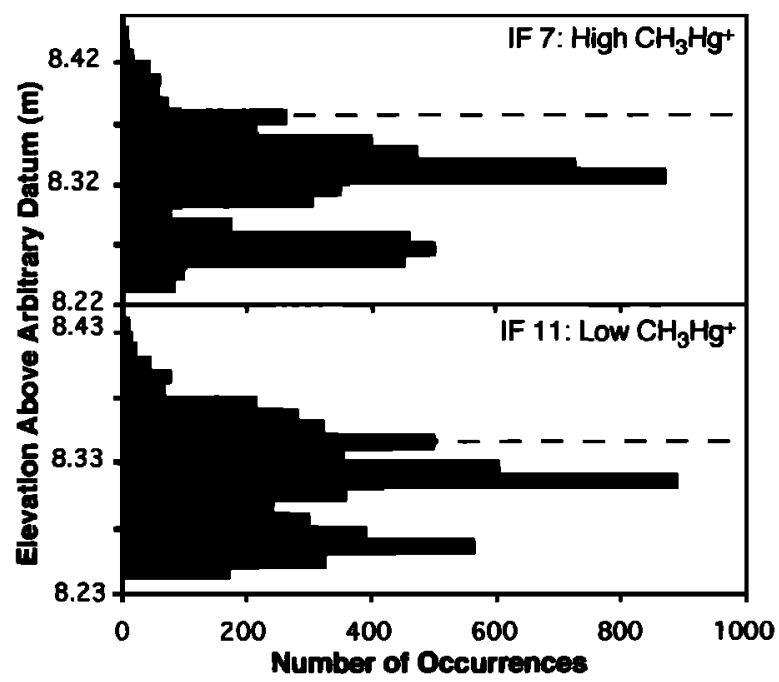

Figure 4. Frequency of mean half hour water table occurrence at IF 7 (groundwater discharge) and IF 11 (groundwater recharge) over the study period. Dashed lines indicate the peat surface elevation above an arbitrary datum.

lowest $K$ was in the deeper peat at IF 1 and IF 2 and in the very dense paludified peat underlying IF 6 .

Hydraulic head varied seasonally, and over shorter time periods in response to rainfall, but the spatial pattern of head generally remained consistent. A discharge zone existed in the "open fen" zone and recharge occurred in the raised peat mound (Figure 5b). Recharge occurred at the hillslopewetland interface and contributed water to subsurface flow through the sand substrate and deeper peat to discharge in the open fen zone and the littoral zone of the pond. The maximum upward gradient in the peatland, measured in the open fen zone, was -0.176 . Water moved down from the peat mound and diverged toward discharge points in the littoral zone of the pond and the open fen behind the bog. The maximum downward hydraulic gradient in the peatland, measured under the bog mound, was 0.153 .

Calculations for mass flux show that between 0.01 and 0.02 $\mathrm{m}^{3} \mathrm{~d}^{-1}$ discharges per linear meter of littoral zone at the edge of the pond. It is estimated that $50 \mathrm{~m}$ of shoreline receives groundwater discharge from the study subcatchment, then the peatland discharges $0.75 \mathrm{~m}^{3} \mathrm{~d}^{-1}$, or $84 \mathrm{~m}^{3}$ over the 112 day period of stream discharge measurement. This value represents a minuscule contribution of water to the pond and loss of water from the compared to that of discharge from the inflow stream $(0.67 \mathrm{~mm}$ versus $229 \mathrm{~mm})$.

The $\delta^{18} \mathrm{O}$ of groundwater ranged from $-14.71 \%$ to $-13.27 \%$ (SMOW) (see Table 1). There was a slight increase in $\delta^{18} \mathrm{O}$ with depth. This was most marked at IF 7 and IF 11. At IF 11 , the $\delta^{18} \mathrm{O}$ was most depleted at $0.50 \mathrm{~m}$. Near-surface samples taken after a rainfall indicated the influence of isotopically heavier rain water on the near-surface $\delta^{18} \mathrm{O}$ in the recharge zones (IF 2 and IF 11), but not in the discharge zones (IF 6 and 7).

\section{Temporal and Spatial Patterns of Methylmercury in the Peatland}

Peat profile concentrations. $\mathrm{CH}_{3} \mathrm{Hg}^{+}$concentration profiles at IF 2/IF 11 (recharge sites) compared to those of IF 6/IF 7 (discharge sites) showed an order of magnitude lower concentration in near-surface pore water (Figure 6). Maximum

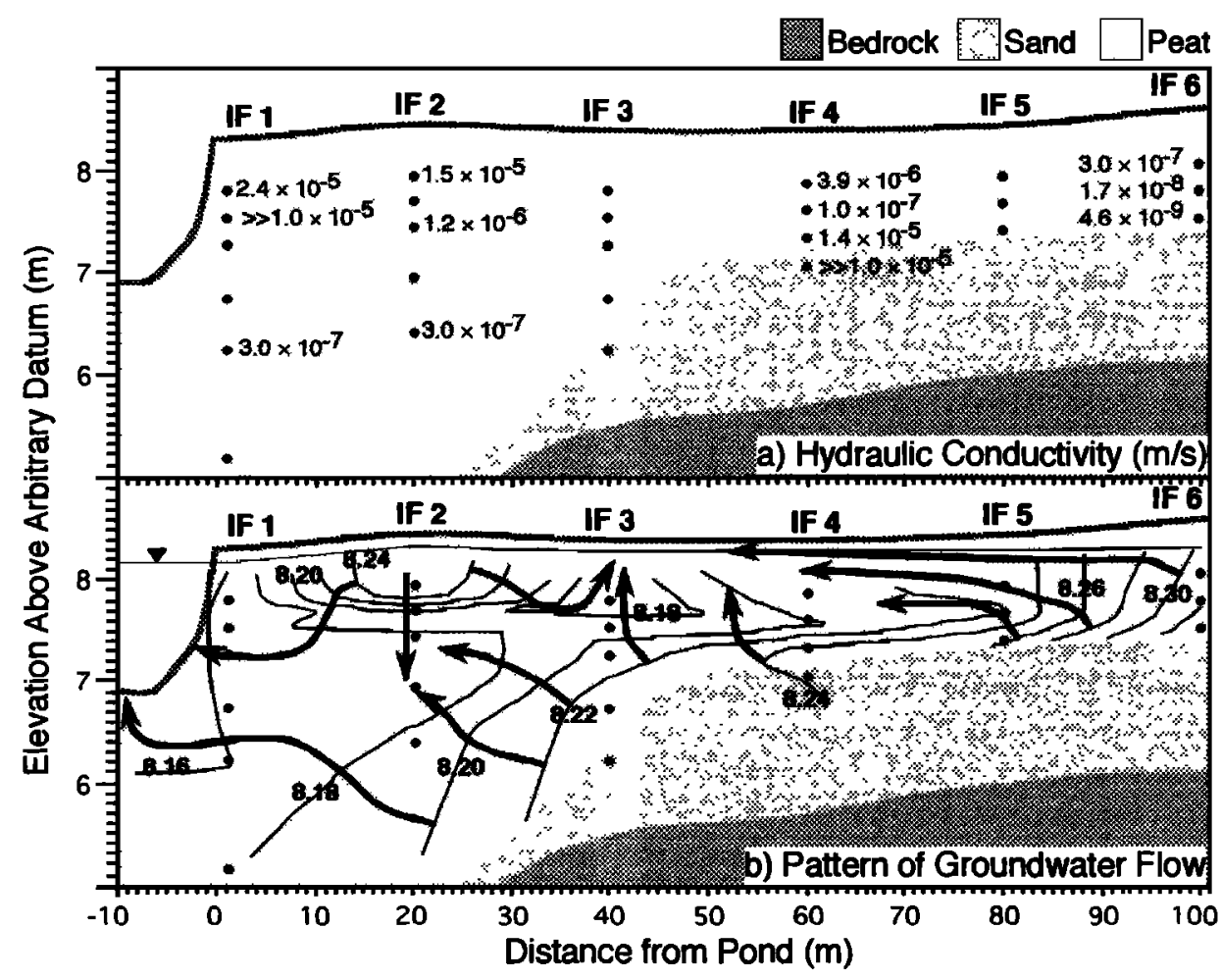

Figure 5. IF 1-6 Transect (east to west parallel to the stream along the long axis of the peatland): (a) hydraulic conductivity and (b) representative flow net depicting groundwater flow. Units of equipotentials are in meters above an arbitrary datum. Arrows indicate direction of flow. Vertical exaggeration is $\times 13$. 
Table 1. Profiles of $\delta^{18} \mathrm{O}$ at Four Piezometer Nests Located in the Inflow Portion of the 632 Peatland at Experimental Lakes Area

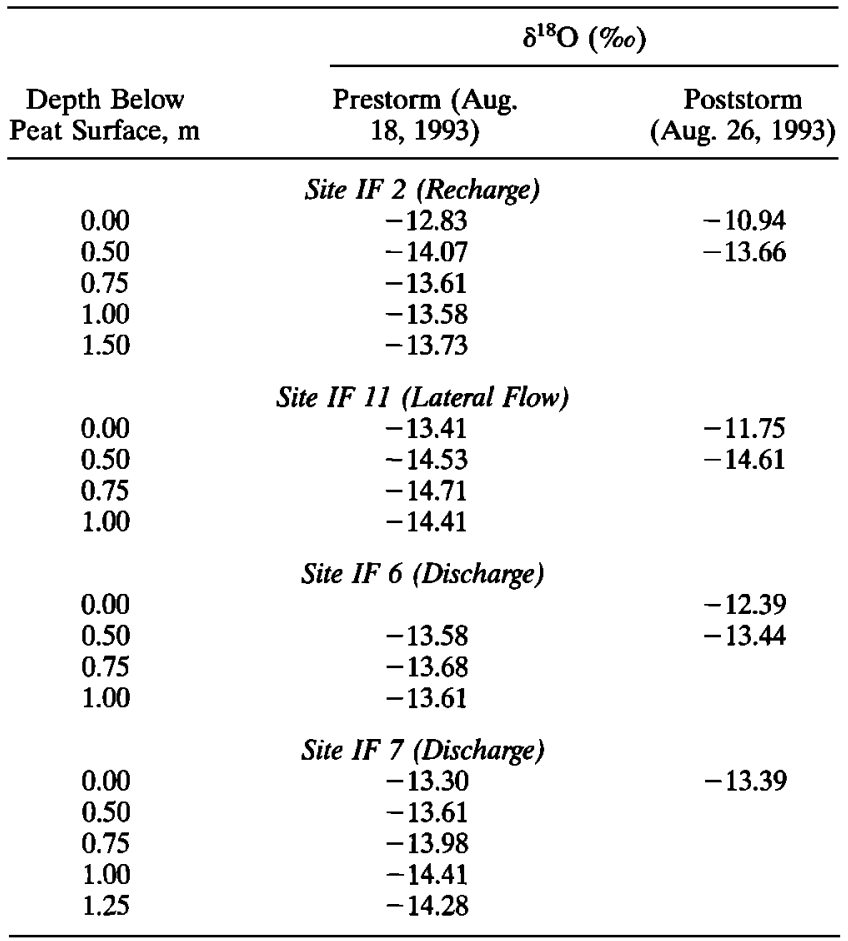

The storm of August 26, 1993 had a rainwater $\delta^{18} \mathrm{O}$ signature of $-6.50 \%$.

concentrations in 1993 at IF 6 and IF 7 were 4.4 and $6.0 \mathrm{ng} \mathrm{L}^{-1}$ at $25 \mathrm{~cm}$ and $30 \mathrm{~cm}$ depth, respectively. In 1994, maximum concentration at IF 7 was lower in August $\left(2.27 \mathrm{ng} \mathrm{L}^{-1}\right.$ at 10 $\mathrm{cm}$ depth), and decreased further in September $\left(1.52 \mathrm{ng} \mathrm{L}^{-1}\right)$, suggesting a temporal variability in $\mathrm{CH}_{3} \mathrm{Hg}^{+}$concentrations. In 1994, additional profiles were obtained approximately $10 \mathrm{~m}$ away from IF 7 in the groundwater discharge zone (IF 12). Maximum concentration measured at IF 12 was $7.26 \mathrm{ng} \mathrm{L}^{-1}$ at $10 \mathrm{~cm}$ below the peat surface. The maximum concentration at IF 12 decreased in September $1994\left(3.93 \mathrm{ng} \mathrm{L}^{-1}\right) . \mathrm{CH}_{3} \mathrm{Hg}^{+}$in the deeper piezometers at IF 7 was relatively low $(0.18-0.46 \mathrm{ng}$ $\mathrm{L}^{-1}$ ) in both 1993 and 1994 . With the water table considerably deeper in the peat profile at IF 6 , no samples were drawn above $30 \mathrm{~cm}$ depth. Relatively high $\mathrm{CH}_{3} \mathrm{Hg}^{+}$concentration ( $2.4 \mathrm{ng} \mathrm{L}^{-1}$ ) was found at $50 \mathrm{~cm}$ at IF 6 , and below this depth, concentrations decreased dramatically.

The profile of $\mathrm{CH}_{3} \mathrm{Hg}^{+}$at IF 2 showed little variation with depth. In 1993, near-surface concentrations were slightly higher $\left(0.41 \mathrm{ng} \mathrm{L}^{-1}\right.$ at $10 \mathrm{~cm}$ and $0.61 \mathrm{ng} \mathrm{L}^{-1}$ at $25 \mathrm{~cm}$ ) than those found at depth $\left(\approx 0.20 \mathrm{ng} \mathrm{L}^{-1}\right)$. In 1994 this trend was exaggerated with maximum and minimum concentrations of $1.10 \mathrm{ng} \mathrm{L}^{-1}$ and $0.03 \mathrm{ng} \mathrm{L}^{-1}$ measured at 25 and $75 \mathrm{~cm}$ depth, respectively. At IF 11, concentrations were nearly constant between 10 and $75 \mathrm{~cm}$ depth $\left(0.50\right.$ to $\left.0.64 \mathrm{ng} \mathrm{L}^{-1}\right)$, decreasing to $0.15 \mathrm{ng} \mathrm{L}^{-1}$ at $150 \mathrm{~cm}$. These results suggest that high near-surface pore water concentrations of $\mathrm{CH}_{3} \mathrm{Hg}^{+}$are a general characteristic of the mineral-poor fen (discharge) and that much lower concentrations are a general characteristic of recharge and lateral flow zones in the peatland.

Base flow stream concentrations. Under base flow conditions, $\mathrm{CH}_{3} \mathrm{Hg}^{+}$concentrations at the stream's origin in the seep ranged from $0.03 \mathrm{ng} \mathrm{L}^{-1}$ shortly after snowmelt to $0.09 \mathrm{ng}$ $\mathrm{L}^{-1}$ in the summer. Midway along the stream, concentrations ranged from 0.15 to $0.24 \mathrm{ng} \mathrm{L}^{-1}$, while at the stream outflow to the pond, concentrations were 0.25 to $0.65 \mathrm{ng} \mathrm{L}^{-1}$ (Figure 7). The highest base flow concentrations were recorded during a very warm, dry period when inflow stream discharge was least. Under base flow conditions, the maximum and mean downstream increase in $\mathrm{CH}_{3} \mathrm{Hg}^{+}$concentration was 0.55 and $0.35 \mathrm{ng}$ $\mathrm{L}^{-1}$, respectively. The mean mass flux of $\mathrm{CH}_{3} \mathrm{Hg}^{+}$to the pond under base flow conditions (using mean baseflow discharge (2.1 $\mathrm{L} \mathrm{s}^{-1}$ ) and the mean baseflow stream $\mathrm{CH}_{3} \mathrm{Hg}^{+}$concentration at the outflow to the lake $\left(0.42 \mathrm{ng} \mathrm{L}^{-1}\right)$ ) was $0.076 \mathrm{mg}$ $\mathrm{d}^{-1}$. The study period was 112 days long, and base flow $(<5 \mathrm{~L}$ $\mathrm{s}^{-1}$ ) occurred $84 \%$ of the time, yielding a total mass flux of 5.3 $\mathrm{mg} \mathrm{CH}_{3} \mathrm{Hg}^{+}$.

Storm flow stream concentrations. A storm on July 26 (day 207) delivered $38 \mathrm{~mm}$ of rainfall between 2030 and 2330 , with the peak rainfall intensity of $30 \mathrm{~mm} \mathrm{~h}^{-1}$ occurring at 2130 . $\mathrm{CH}_{3} \mathrm{Hg}^{+}$concentration of the bulk precipitation sample was $0.037 \mathrm{ng} \mathrm{L}^{-1}$. The rain fell on a "wet" subcatchment, resulting in a lag time between peak rainfall and peak discharge (16.2 L $\mathrm{s}^{-1}$ on July 27) of 10 hours. The first set of $\mathrm{CH}_{3} \mathrm{Hg}^{+}$samples were taken at 1300 on July 27 , with subsequent samples taken on July 28 (1300) and July 30 (900). Inflow stream discharge was still high, and runoff was being contributed by the nearstream zone, the peatland, and the upland portion of the subcatchment via saturation overland flow and shallow subsurface stormflow [Fowle, 1994].

On July $27, \mathrm{CH}_{3} \mathrm{Hg}^{+}$concentration at the hillslope seep was $0.16 \mathrm{ng} \mathrm{L}^{-1}$, nearly double the prestorm baseflow concentration (Figure 8). This resulted from the mixing of higher$\mathrm{CH}_{3} \mathrm{Hg}^{+}\left(0.23 \mathrm{ng} \mathrm{L}^{-1}\right)$ saturation overland flow near the hillslope-peatland interface with the lower- $\mathrm{CH}_{3} \mathrm{Hg}^{+}\left(0.07 \mathrm{ng} \mathrm{L}^{-1}\right)$ groundwater emerging at the seep. The increased concentration was maintained for nearly 4 days after the storm. After the storm event, surface water in the vicinity of IF 7 had a $\mathrm{CH}_{3} \mathrm{Hg}^{+}$ concentration of $0.64 \mathrm{ng} \mathrm{L}^{-1} \cdot \mathrm{CH}_{3} \mathrm{Hg}^{+}$concentrations in the stream outflow near the pond increased from $0.28 \mathrm{ng} \mathrm{L}^{-1}$ on July 28 to $0.53 \mathrm{ng} \mathrm{L}^{-1}$ on July 31 (Figure 7). Four days after the rainfall, the maximum and mean downstream increase in $\mathrm{CH}_{3} \mathrm{Hg}^{+}$were 0.43 and $0.23 \mathrm{ng} \mathrm{L}^{-1}$, respectively. The elevated storm $\mathrm{CH}_{3} \mathrm{Hg}^{+}$concentration at the stream origin at the seep shows the result of the mixing of dilute groundwater and upland saturation overland flow. Precipitation $\mathrm{CH}_{3} \mathrm{Hg}^{+}$concen-

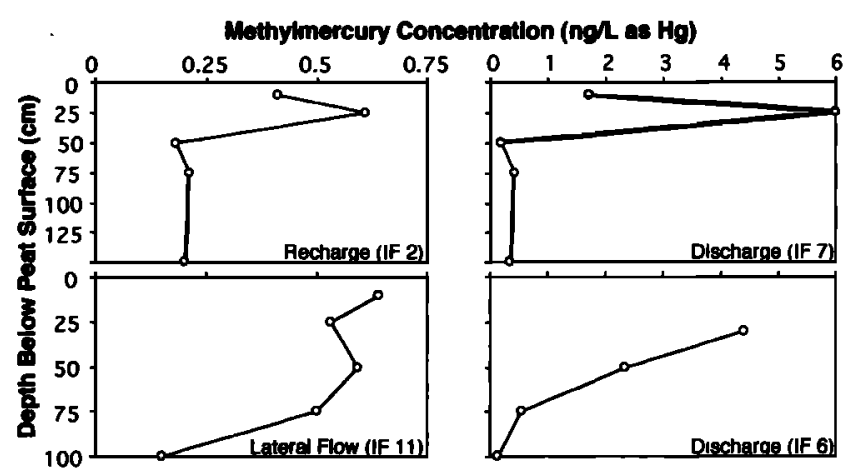

Figure 6. $\mathrm{CH}_{3} \mathrm{Hg}^{+}$concentration profiles at four piezometer nests in the 632 peatland. IF 2 and IF 11 are located in a groundwater discharge zone and lateral flow zone respectively, while IF 6 and IF 7 are located in a groundwater discharge zone. 


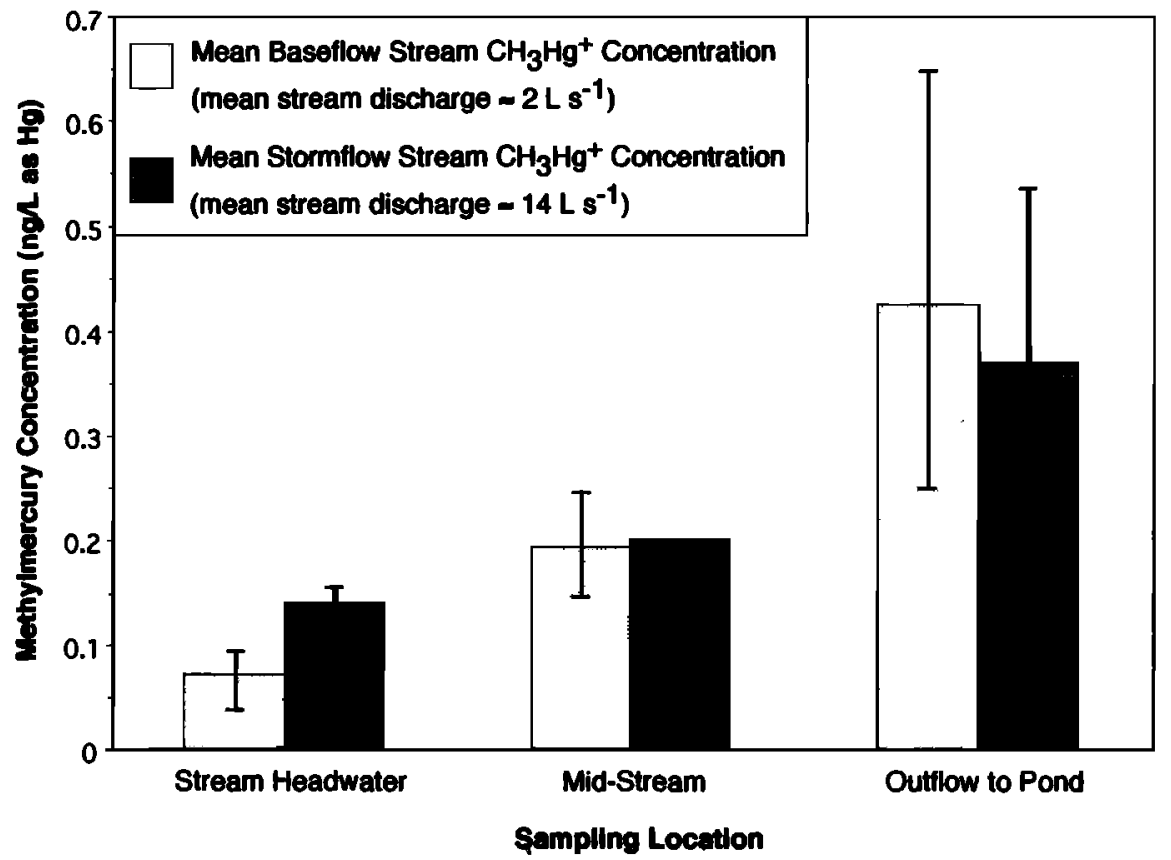

Figure 7. Mean $\mathrm{CH}_{3} \mathrm{Hg}^{+}$concentrations in the inflow stream from the seep origin to the outflow to the pond under base flow discharge $\left(\approx 2 \mathrm{~L} \mathrm{~s}^{-1}\right)$, and storm flow discharge $\left(\approx 14 \mathrm{~L} \mathrm{~s}^{-1}\right)$ after a rainfall on July $27-28$, 1993. Error bars indicate the range of concentrations observed at each sampling site. Only one set of samples were taken at the midstream location under storm flow conditions. Distance from the stream headwater to the outflow is approximately $100 \mathrm{~m}$.

tration is clearly too low to account for the concentrations observed in the stream and storm runoff; however, it approaches the concentration of the hillslope groundwater.

The mean mass flux of $\mathrm{CH}_{3} \mathrm{Hg}^{+}$to the pond under storm flow conditions using a mean storm flow stream $\mathrm{CH}_{3} \mathrm{Hg}^{+}$concentration $\left(0.37 \mathrm{ng} \mathrm{L}^{-1}\right)$ and mean storm flow discharge (14.2 $\mathrm{L} \mathrm{s}^{-1}$ ) was $0.45 \mathrm{mg} \mathrm{d}^{-1}$, which on a daily basis is 6 times larger than that of base flow. However, storm flow occurred over $16 \%$ of the time during the study period, yielding a contribution of $7.3 \mathrm{mg}$ of $\mathrm{CH}_{3} \mathrm{Hg}^{+}$to the pond. The total flux of $\mathrm{CH}_{3} \mathrm{Hg}^{+}$to the pond via the inflow stream for the entire 112-day period of streamflow measurement was $12.6 \mathrm{mg}$; therefore $53 \%$ of the mass flux of $\mathrm{CH}_{3} \mathrm{Hg}^{+}$occurred under stormflow conditions.

Methylmercury transport by groundwater to the pond. Direct $\mathrm{CH}_{3} \mathrm{Hg}^{+}$contributions to the pond were derived using a $\mathrm{CH}_{3} \mathrm{Hg}^{+}$concentration of $0.2 \mathrm{ng} \mathrm{\textrm {L } ^ { - 1 }}$ based on the concentration of deeper samples taken at IF 2 and a groundwater discharge of $0.75 \mathrm{~m}^{3} \mathrm{~d}^{-1}$ calculated in the groundwater flow section ( $84 \mathrm{~m}^{3}$ total discharge for the study period) to the upstream littoral zone of the pond. The mass flux to the pond was $150 \mathrm{ng} \mathrm{CH} \mathrm{CH}^{+} \mathrm{d}^{-1}$, representing a total contribution of only $0.02 \mathrm{mg} \mathrm{CH} \mathrm{CHg}^{+}$over the study period. This is a negligible fraction compared with that of the streamflow. If $\mathrm{CH}_{3} \mathrm{Hg}^{+}$concentrations continued to decline with depth as is indicated by the concentration profiles, then it is likely that the mass flux of $\mathrm{CH}_{3} \mathrm{Hg}^{+}$to the lake via groundwater is even lower than $150 \mathrm{ng} \mathrm{d}^{-1}$.

\section{Discussion}

\section{Hydrology}

In this subcatchment there are two flow regimes that influence the transport of $\mathrm{CH}_{3} \mathrm{Hg}^{+}$: base flow, maintained by a seep at the base of the hillslope and groundwater discharge in the peatland, and storm flow, which is generated from hillslope runoff and lateral saturation overland flow generated in the peatland itself. The storm flow on the surface of the peatland is superimposed on a spatially variable groundwater flow regime in the peatland. There are three distinct groundwater patterns: a zone of groundwater recharge under the raised peat mound, a groundwater discharge zone in the center of the peatland where a mineral-poor fen is located, and a zone of lateral groundwater flow near the surface of the peatland between these zones and beneath the peatland in the mineral substrate. During storm flow there are two different runoff response patterns depending on the antecedent moisture condition [Fowle, 1994]. The storm analyzed in this study occurred on a "wet" catchment and resulted in a large stream discharge generated both within the peatland and from the hillslope adjacent to the peatland. While storm flow occurred much less frequently than base flow ( $16 \%$ versus $84 \%$ of the time), it represented a little over $55 \%$ of the mass flux of water over the study period.

\section{Flow Paths and Methylmercury Transport}

$\mathrm{CH}_{3} \mathrm{Hg}^{+}$was transported by two flow paths. The most important pathway was surface stream flow across the peatland, with an average flux of $0.11 \mathrm{mg} \mathrm{CH} \mathrm{CH}_{3} \mathrm{H}^{-1}(12.6 \mathrm{mg}$ $\mathrm{CH}_{3} \mathrm{Hg}^{+}$over 112 days). The second pathway was groundwater discharge from the peat through the littoral zone to the pond. This mass flux of only $150 \mathrm{ng} \mathrm{CH} \mathrm{CHg}_{3} \mathrm{~d}^{-1}\left(0.02 \mathrm{mg} \mathrm{CH} \mathrm{Hg}^{+}\right.$ over 112 days) is insignificant in comparison with that of surface flow because of the combination of a low mass flux of water and low $\mathrm{CH}_{3} \mathrm{Hg}^{+}$concentration in the water. No other studies have directly examined the transport of $\mathrm{CH}_{3} \mathrm{Hg}^{+}$to northern Precambrian Shield lakes by groundwater flow, but 


\section{Stream Discharge and Methylmercury Concentrations in Precipltation, Runoff and Streamflow During a Storm Event: July 27-August 1, 1993}

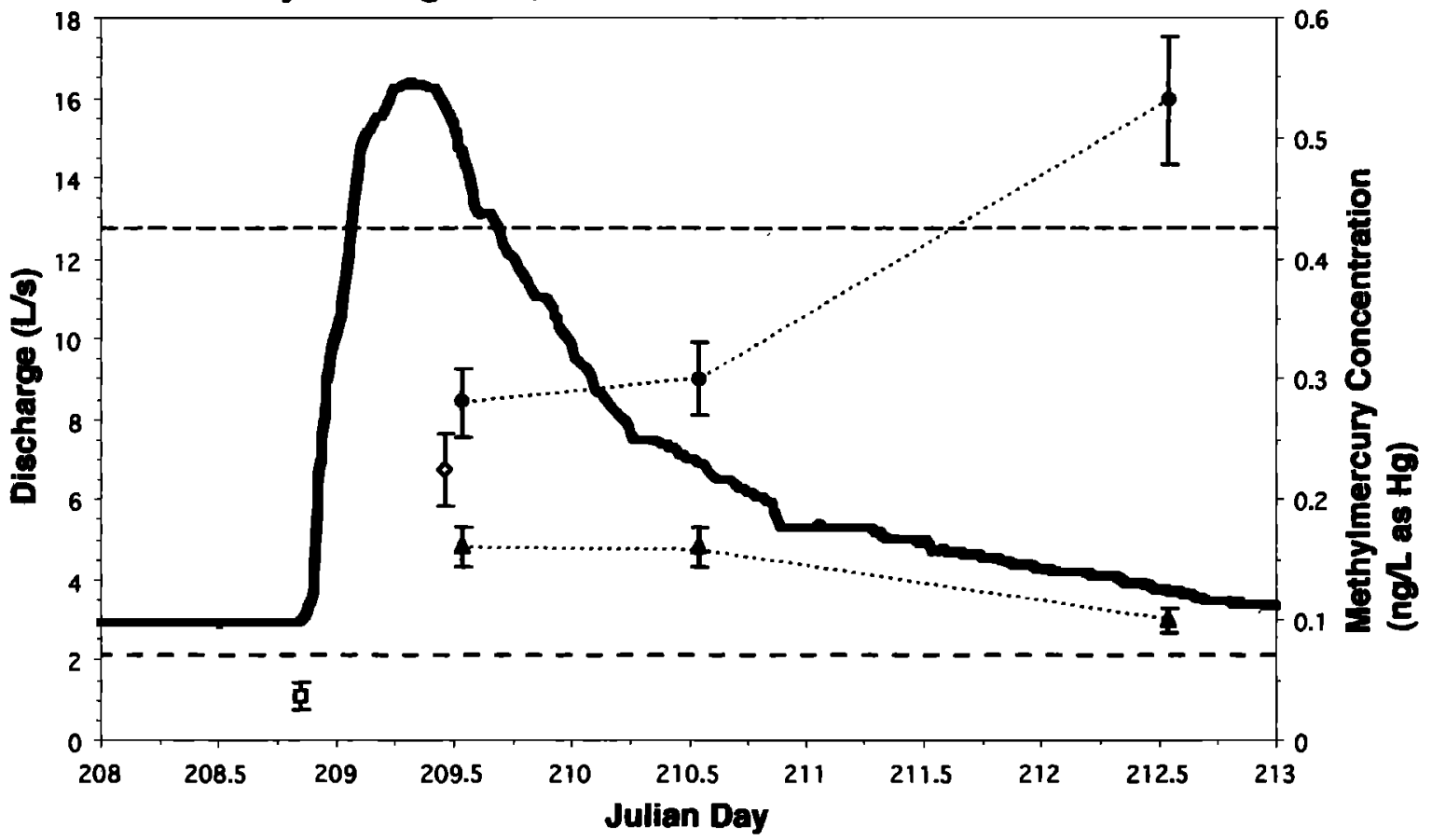

\begin{tabular}{|c|c|}
\hline $\begin{array}{c}- \\
- \\
.0 \\
. \bullet \\
. \bullet \\
\bullet \\
0\end{array}$ & $\begin{array}{l}\text { - Mean Baseflow } \mathrm{CH}_{3} \mathrm{Hg}^{+} \text {Concentration at Seep } \\
\text { Mean Baseflow } \mathrm{CH}_{3} \mathrm{Hg}^{+} \text {Concentration at Stream Outflow to Pond } \\
\text { Storm } \mathrm{CH}_{3} \mathrm{Hg}^{+} \text {Concentration at Seep } \\
\text { Stom } \mathrm{CH}_{3} \mathrm{Hg}^{+} \text {Concentration at Stream Outflow to Pond } \\
\text { Upland Rumoff } \mathrm{CH}_{3} \mathrm{Hg}^{+} \text {Concentration } \\
\text { Precipitation } \mathrm{CH}_{3} \mathrm{Hg}^{+} \text {Concentration }\end{array}$ \\
\hline
\end{tabular}

Figure 8. $\mathrm{CH}_{3} \mathrm{Hg}^{+}$concentrations in the inflow stream plotted with the inflow stream hydrograph for July 27 to August 1, 1993. Lines connecting storm $\mathrm{CH}_{3} \mathrm{Hg}^{+}$stream concentrations are inferred for clarity.

Krabbenhoft and Babiarz [1992] demonstrated that the groundwater system influencing a seepage lake in Wisconsin was a net sink for total $\mathrm{Hg}$, and others have shown that biogeochemical transfer at the lake-sediment interface was key to the chemical exchange between sediments and water [e.g., Rudd et al., 1986]. It is unknown whether there are any sediment-water interface processes at work in this peatland that would affect the contribution of $\mathrm{CH}_{3} \mathrm{Hg}^{+}$to the downstream system by groundwater.

The sevenfold to eightfold $\left(0.03-0.09\right.$ to $0.25-0.65 \mathrm{ng} \mathrm{L}^{-1}$ $\mathrm{CH}_{3} \mathrm{Hg}^{+}$) increase in streamflow concentration from the hillslope base to the pond under base flow suggests that $\mathrm{CH}_{3} \mathrm{Hg}^{+}$ was being contributed to the stream from the peatland. Mean groundwater discharge of $0.025 \mathrm{~m}^{3} \mathrm{~d}^{-1}$ per linear meter of stream, based on the vertical gradients under the stream multiplied by the observed $\mathrm{CH}_{3} \mathrm{Hg}^{+}$concentration of $0.50 \mathrm{ng} \mathrm{L}^{-1}$ in the near-streambed zone, can account for a flux of only 0.001 $\mathrm{mg} \mathrm{d}^{-1}$, or $<2 \%$ of the total base flow $\mathrm{CH}_{3} \mathrm{Hg}^{+}$to the pond. Therefore additional potential sources of $\mathrm{CH}_{3} \mathrm{Hg}^{+}$to the stream have to be considered. Laboratory incubations of inflow streambed sediments indicate that net methylation could contribute between 5 and $12 \mathrm{ng} \mathrm{m^{-2 }} \mathrm{d}^{-1}$ (P. Sellers, personal communication, 1994), but assuming production occurs over the entire length of the stream, an average net methylation rate of approximately $1800 \mathrm{ng} \mathrm{m}^{-2} \mathrm{~d}^{-1}$ is required to maintain the observed increase in concentration. The $1800 \mathrm{ng} \mathrm{m}^{-2} \mathrm{~d}^{-1}$ was computed from the mean downstream change in $\mathrm{CH}_{3} \mathrm{Hg}^{+}$ ( $0.35 \mathrm{ng} \mathrm{L}^{-1}$ ) concentration multiplied by the mean stream water flux per day $\left(259,200 \mathrm{~L} \mathrm{~d}^{-1}\right)$ divided by the area of the streambed $\left(\approx 50 \mathrm{~m}^{2}\right)$. Clearly, stream methylation is not the source. An alternative hypothesis is that the $\mathrm{CH}_{3} \mathrm{Hg}^{+}$concentration increase is the result of seepage to the stream of high$\mathrm{CH}_{3} \mathrm{Hg}^{+}$pore water from the streamside zone. The range of observed downstream increase of $\mathrm{CH}_{3} \mathrm{Hg}^{+}$would require a mixing of only $<1 \%$ to $7.5 \%$ of the stream water with methylmercury-laden near-stream interstitial water.

During large summer storms there is a coupling of the upland and peatland surface hydrologic systems which results in a substantial increase in stream $\mathrm{CH}_{3} \mathrm{Hg}^{+}$export. The $\mathrm{CH}_{3} \mathrm{Hg}^{+}$ concentration in the upland storm flow contribution to the peatland was $0.23 \mathrm{ng} \mathrm{L}^{-1}$. If this upland flow was the sole source of $\mathrm{CH}_{3} \mathrm{Hg}^{+}$to sustain the increase in $\mathrm{CH}_{3} \mathrm{Hg}^{+}$export in storms, then the concentration should drop from the stream origin at the seep to the pond inflow owing to dilution by runoff generated in the peatland itself. However, even with a fivefold increase in stream flow during storm flow conditions, there is still a large increase in $\mathrm{CH}_{3} \mathrm{Hg}^{+}$concentration. This increase is $\approx 0.75$ of that observed under base flow conditions. In addition, although the stream concentration at the outflow to the pond 
was slightly diluted during high flows, when the hydrograph was dominated by upland runoff with a lower $\mathrm{CH}_{3} \mathrm{Hg}^{+}$concentration, it rose to above average during the recession limb of the hydrograph, when stream flow was sustained solely by water derived from within the peatland. The differences in the seep concentrations and the stream outflow concentrations at the pond can be explained only by $\mathrm{CH}_{3} \mathrm{Hg}^{+}$addition to the stream as water passes through the peatland. This increase in $\mathrm{CH}_{3} \mathrm{Hg}^{+}$concentration in the inflow stream sustained during large rainfalls indicates that there is a large intrawetland source of $\mathrm{CH}_{3} \mathrm{Hg}^{+}$and that the stream concentration is largely controlled by intrapeatland runoff processes.

Methylmercury-laden near-surface peat pore water of the mineral-poor fen zone is the most likely source of the stream $\mathrm{CH}_{3} \mathrm{Hg}^{+}$under storm flow conditions. The area that contributes storm runoff to the inflow stream is variable, and its extent depends upon antecedent moisture conditions in the subcatchment. If rain occurs when the water table is high (e.g., July 26), runoff is contributed by the peatland portion of the subcatchment by shallow subsurface storm flow and saturation overland flow, and from the base of the upland hillslope by saturation overland flow and return flow. Upland saturation overland flow contributes the bulk of the storm runoff and controls the timing and magnitude of the hydrograph peak. In the peatland, as the water table rises through the peat profile during a storm, water begins to flow through zones of increasing transmissivity in the mineral poor fen, which allows for water to pass through and mix more effectively with the near-surface zone of methylmercury-laden pore water. It is this methylmercury-laden peatland runoff that produces the downstream increase in concentration observed during storms.

The downstream increase in concentration persists for a number of days after a storm, which suggests that the store of $\mathrm{CH}_{3} \mathrm{Hg}^{+}$is large and/or that production of $\mathrm{CH}_{3} \mathrm{Hg}^{+}$is at least equal to the flushing rate. We think that the former is the more plausible. The flushing of near-surface soil horizons as a mechanism of delivering $\mathrm{CH}_{3} \mathrm{Hg}^{+}$to the stream is similar to that proposed by Lynch and Corbett [1989] to explain the simultaneous occurrence of high stream discharge and high stream water sulfate concentrations. However, Bishop et al. [1995a] observed a drop in $\mathrm{CH}_{3} \mathrm{Hg}^{+}$concentration with an increase in discharge in a stream originating in a riparian wetland. Although still representing a potential source of $\mathrm{CH}_{3} \mathrm{Hg}^{+}[$Bishop et al., 1995b], the riparian wetland in the Bishop et al. [1995a] study represented a much smaller proportion of the basin and occupied only the streamside environment relative to the peatland in the present study, making its runoff far more susceptible to dilution effects, as was found by St. Louis et al. [1994].

\section{Sources of Methylmercury}

Very high $\mathrm{CH}_{3} \mathrm{Hg}^{+}$concentrations in the near-surface peat pore water at the groundwater discharge sites suggest that there are conditions present here that are conducive to the accumulation or production of methylmercury, but we have not yet found an explanation for this occurrence. However, a number of different observations suggest potential reasons. First, the groundwater discharge zone in the mineral-poor fen is an area in which there is a convergence of at least three flow systems, while no near-surface convergence of surface and subsurface flow systems is possible at either groundwater discharge or lateral flow-through sites. Second, near-surface water $\delta^{18} \mathrm{O}$ signatures at the discharge sites $(\approx-13.6 \%$ ) com- pared with samples from the same depths at the recharge sites ( $-14.07 \%$ and $-14.53 \%$, respectively) suggest differences in the groundwater source area. These data indicate that groundwater discharge and/or the convergence of surface and subsurface flow systems (likely with specific contributing areas) is a necessary requirement for the significant production/accumulation of $\mathrm{CH}_{3} \mathrm{Hg}^{+}$in near-surface peat. The groundwater source could be important in maintaining anaerobic conditions [e.g., Watras and Bloom, 1992] and/or providing a biogeochemical environment conducive to $\mathrm{CH}_{3} \mathrm{Hg}^{+}$production.

It has been demonstrated by this investigation and other work at the ELA (A. Heyes, unpublished data, 1995) that the highest concentrations of $\mathrm{CH}_{3} \mathrm{Hg}^{+}$are found in the nearsurface peat pore water in wetlands. These depths coincide, in most cases, with the transition between the aerobic and anaerobic zones in the peat profile and hence may be related to frequency of water table occurrence (i.e., a purely physical control). However, this study shows no difference in the frequency of water table occurrence between sites with high and low $\mathrm{CH}_{3} \mathrm{Hg}^{+}$concentrations in the peat profile (Figures 4 and 6).

The groundwater discharge environment of the mineralpoor fen is no more "stable" than that of the recharge or lateral flow zones, even though it was a zone of groundwater discharge over the study period. The results of other studies [Gilmour and Henry, 1991; Watras and Bloom, 1992] have demonstrated that anaerobic conditions promote the formation and stability of $\mathrm{CH}_{3} \mathrm{Hg}^{+}$. The maintenance of anaerobicity is ensured in the mineral-poor fen by persistent groundwater discharge and hence high water tables. However, persistent anaerobicity cannot be the sole factor in the development and maintenance of the high- $\mathrm{CH}_{3} \mathrm{Hg}^{+}$sites, since this condition is duplicated in many other locations in the peatland where $\mathrm{CH}_{3} \mathrm{Hg}^{+}$concentrations are low.

Hydrologic flow paths play a role by relocating and concentrating $\mathrm{CH}_{3} \mathrm{Hg}^{+}$that has been produced in other locations, and/or providing inorganic mercury for methylation in situ, and/or providing nutrients to sustain the methylation of inorganic mercury. The first two processes are unlikely, since there is no evidence in peat pore water concentration profiles to suggest that hillslope water is transported and relocated in such a way that would result in the pockets of high $\mathrm{CH}_{3} \mathrm{Hg}^{+}$ concentrations, and the store of inorganic mercury in peatland vegetation and pore water is more than sufficient to provide enough mercury for in situ methylation [Moore et al., 1995].

It has been shown that mercury methylation is primarily a microbial process, and although the organism(s) and the processes involved in the transformation are not yet well understood, $\mathrm{Hg}$ methylation has been shown to be dependent on the availability of nutrients such as sulfate [Gilmour and Henry, 1991; Compeau and Bartha, 1984, 1985]. Assuming that methylating microbes are ubiquitous and that the supply of inorganic mercury in the peatland is large (in decaying peatland vegetation and in peat pore water), nutrient availability may be the limiting factor in mercury methylation, and variation in hydrologic flow pathways may result in variations in the supply of limiting nutrients.

In summary, the results of this study indicate that the hydrology of northern Precambrian Shield peatlands not only plays a role in the mass flux of $\mathrm{CH}_{3} \mathrm{Hg}^{+}$to downstream aquatic ecosystems, but may also influence the production and/or accumulation of methylmercury in the peatland itself. These results provide a partial explanation for the findings of St. Louis 
et al. [1994] and are in agreement with recent work [Bishop et $a l ., 1995 \mathrm{a}, \mathrm{b} ; \mathrm{Krabbenhoft}$ et al., 1995] that has found relatively high methylmercury concentrations in peat, particularly in groundwater discharge zones.

Acknowledgments. Thanks to N. Comer, R. Flett, R. Geater, E. Mewhinney, V. St. Louis, K. Sanmugadas, and K. Savage for field, lab and technical assistance. Support from the ELA staff was greatly appreciated; special thanks to $\mathrm{K}$. Beaty and $\mathrm{M}$. Lyng for hydrologic data. Our gratitude to A. Hill, C. Kelly, A. Robert, J. Rudd, and V. St. Louis for commenting on previous versions of this manuscript, and special thanks to C. Driscoll and D. Siegel for their insightful reviews. B. Branfireun was supported by a NSERC Postgraduate Scholarship. This research was funded by a NSERC Research Grant, and a Hydro Quebec grant to N. Roulet, and a Manitoba Hydro grant to A. Heyes and T. Moore. Experimental Lakes Area Reservoir Project (ELARP) contribution 14.

\section{References}

Aastrup, M., J. Johnson, E. Bringmark, I. Bringmark, and Å. Iverfeldt, Occurrence and transport of mercury within a small catchment area, Water Air Soil Pollut., 56, 155-167, 1991.

Beaty, K. G., and M. E. Lyng, Hydrometeorological data for the Experimental Lakes Area, northwestern Ontario, 1982 to 1987, Can. Data Rep. Fish. Aquat. Sci., 759, 280 pp., 1989.

Bishop, K., Y-H. Lee, C. Petterson, and B. Allard, Methylmercury in runoff from the Svartberget catchment in northern Sweden during a stormflow episode, Water Air Soil Pollut., 80, 221-224, 1995a.

Bishop, K., Y-H. Lee, C. Petterson, and B. Allard, Terrestrial sources of methylmercury in surface waters: The importance of the riparian zone on the Svartberget catchment, Water Air Soil Pollut., 80, 435$444,1995 b$.

Bloom, N. S., On the chemical form of mercury in edible fish and marine invertebrate tissue, Can. J. Fish. Aquat. Sci., 49, 1010-1017, 1992.

Bloom, N. S., and W. F. Fitzgerald, Determination of volatile mercury species at the picogram level by low temperature gas chromatography with cold-vapor atomic fluorescence detection, Anal. Chim. Acta, 208, 151-161, 1988.

Compeau, G. C., and R. Bartha, Methylation and demethylation of mercury under controlled redox, $p \mathrm{H}$ and salinity conditions, $A p p l$. Environ. Microbiol., 48, 1203-1207, 1984.

Compeau, G. C., and R. Bartha, Sulfate-reducing bacteria: Principal methylators or mercury in anoxic estuarine sediment, Appl. Environ. Microbiol., 50, 498-502, 1985.

Driscoll, C. T., C. Yen, C. L. Schofield, R. Munson, and J. Holsapple, The chemistry and bioavailability of mercury in remote Adirondack lakes, Environ. Sci. Technol., 28, 136A-143A, 1994.

Fitzgerald, W. F., and C. J. Watras, Mercury in surficial waters of rural Wisconsin lakes, Sci. Total Environ., 87/88, 223-232, 1989.

Fowle, B. A., The hydrology of a Precambrian Shield peatland: Controls on methylmercury formation and flux, M.Sc. thesis, York Univ., Toronto, Ont., Canada, 1994.

Freeze, R. A., and J. A. Cherry, Groundwater, Prentice-Hall, Englewood Cliffs, N. J., 1979.

Gilmour, C. C., and E. A. Henry, Mercury methylation in aquatic systems affected by acid deposition, Environ. Pollut., 71, 131-169, 1991.

Hemond, H. F., Biogeochemistry of Thoreau's bog, Concord, Massachusetts, Ecol. Monogr., 50(4), 507-526, 1980.
Horvat, M., N. S. Bloom, and L. Liang, Comparison of distillation with other current isolation methods for the determination of methyl mercury compounds in low level environmental samples, 1 , Sediments, Anal. Chim. Acta, 281, 135-152, 1993.

Iverfeldt, $\AA$., Mercury in forest canopy throughfall water and its relation to atmospheric deposition, Water Air Soil Pollut., 56, 553-564, 1991.

Iverfeldt, $\AA$., and K. Johansson, Mercury in run-off water from small watersheds, Verh. Int. Ver. Theor. Angew. Limnol., 23, 2917-2925, 1988.

Kelly, C. A., J. W. M. Rudd, V. L. St. Louis, and A. Heyes, Is total mercury concentration a good predictor of methyl mercury concentrations in aquatic systems?, Water Air Soil Pollut., 80, 715-724, 1995.

Krabbenhoft, D. P., and C. L. Babiarz, The role of groundwater transport in aquatic mercury cycling, Water Resour. Res., 28(12), 3119$3128,1992$.

Krabbenhoft, D. P., J. M. Benoit, C. L. Babiarz, J. P. Hurley, and A. W. Andren, Mercury cycling in the Allequash Creek watershed, northern Wisconsin, Water Air Soil Pollut., 80, 425-433, 1995.

Lindqvist, O., K. Johansson, M. Aastrup, A. Andersson, L. Bringmark, G. Hovenius, L. Hakanson, Å. Iverfelt, M. Meili, and B. Timm, Mercury in the Swedish environment-Recent research on causes, consequences and corrective methods, Water Air Soil Pollut., 55, $1-261,1991$.

Lynch, J. A., and E. S. Corbett, Hydrologic control of sulfate mobility in a forested watershed, Water Resour. Res., 25(7), 1695-1703, 1989.

Meili, M., The coupling of mercury and organic matter in the biogeochemical cycle-Towards a mechanistic model for the boreal forest zone, Water Air Soil Pollut., 56, 333-347, 1991

Moore, T. R., J. L. Bubier, A. Heyes, and R. J. Flett, Methyl and total mercury in boreal wetland plants, Experimental Lakes Area, northwestern Ontario, J. Environ. Qual., 24, 845-850, 1995.

Rudd, J. W. M., Sources of methyl mercury to freshwater ecosystems A review, Water Air Soil Pollut., 80, 697-713, 1995.

Rudd, J. W. M., C. A. Kelly, and A. Furutani, The role of sulfate reduction in long term accumulation of organic and inorganic sulfur in lake sediments, Limnol. Oceanogr., 31, 1281-1291, 1986.

Siegel, D. I., and P. H. Glaser, Groundwater flow in a bog-fen complex, Lost River Peatland, northern Minnesota, J. Ecol., 75, 743-754, 1987.

Sorenson, J. A., G. E. Glass, K. W. Schmidt, J. K. Huber, and G. R. Rapp, Airborne mercury deposition and watershed characteristics in relation to mercury concentrations in water sediments, plankton and fish of eighty northern Minnesota lakes, Environ. Sci. Technol., 24, $1716-1727,1990$

St. Louis, V. L., J. W. M. Rudd, C. A. Kelly, K. G. Beaty, N. S. Bloom, and $\mathbf{R}$. J. Flett, Importance of wetlands as sources of methyl mercury to boreal forest ecosystems, Can. J. Fish. Aquat. Sci., 51, 1065-1076, 1994.

Watras, C. J., and N. Bloom, Mercury and methylmercury in individual zooplankton: Implications for bioaccumulation, Limnol. Oceanogr., 36, 1313-1318, 1992.

Verry, E. S., and D. R. Timmons, Waterborne nutrient flow through an upland-peatland watershed in Minnesota, Ecology, 63(5), 1456$1467,1982$.

B. A. Branfireun, A. Heyes, and N. T. Roulet, Department of Geography, Burnside Hall, McGill University, 805 Sherbrooke Street West, Montréal, Québec, Canada H3A 2K6. (e-mail: roulet@felix. geog.mcgill.ca)

(Received January 22, 1996; revised March 11, 1996; accepted March 12, 1996.) 